\title{
Paleomagnetism of the Shimokura Dike Swarm in Northeast Japan
}

\author{
Hideo Tsunakawa ${ }^{1}$, Kosuke HeKI ${ }^{2}$, and Kazuo Amano ${ }^{3}$ \\ ${ }^{1}$ Institute of Research and Development, Tokai University, Hiratsuka, Kanagawa, \\ Japan \\ ${ }^{2}$ Kashima Space Communication Center, Radio Research Laboratories, Ministry of \\ Posts and Telecommunications, Kashima, Ibaraki, Japan \\ ${ }^{3}$ Department of Earth Sciences, Ibaraki University, Mito, Ibaraki, Japan
}

(Received March 29, 1985; . Revised May 31, 1985)

\section{Introduction}

A dike swarm is the subterranean volcanism of more than several tens of intrusions. The subaerial volcanism of a single volcano generally persists its activity for $10^{4}-10^{5}$ years (e.g., KUNO, 1976). A dike swarm is also considered to be formed in the same time interval as that of the subaerial one (NAKAMURA, 1977). Such time interval is considered to be sufficient to average out the geomagnetic secular variation (HEKI, 1983). Dike rocks are volcanic ones so that they have thermo-remanent magnetization which can yield reliable paleomagnetic data and that we can date them by some radiometric method. Furthermore, we find that dike swarms have occurred at many places throughout geological time. Dike swarms can be, therefore, used as a good tool to study paleomagnetism in spite of the uncertainty of the time sequence of individual intrusions.

In the present study, the Shimokura dike swarm, formed in the Late Miocene in Northeast Japan, was paleomagnetically investigated to analyze the palesecular variation and to detect the tectonic movement of Northeast Japan.

\section{Geology and Paleomagnetic Measurements}

The Shimokura dike swarm is a part of more than one hundred dikes intruding into the Late Miocene tuffs, the Shirasawa Group, Miyagi Prefecture in Northeast Japan (AMANO, 1980; Fig. 1). This area was studied for baked contact test by KATO et al. (1954), which indicates the dikes in this area did not thermally affect each other. The dike rocks are composed of basalt, andesite and dacite. The $\mathrm{K}-\mathrm{Ar}$ ages of about $8 \mathrm{MaBP}$ were obtained by TsunAKAWA et al. (1983). Each dike ranges in width from $40 \mathrm{~cm}$ to $10 \mathrm{~m}$ and cuts the bedding plane of host rocks almost vertically. Because the host tuffs have nearly horizontal bedding plane, the tilting correction is considered to be unnecessary for paleomagnetic results of the dike rocks.

More than four independently oriented samples were taken from each of 

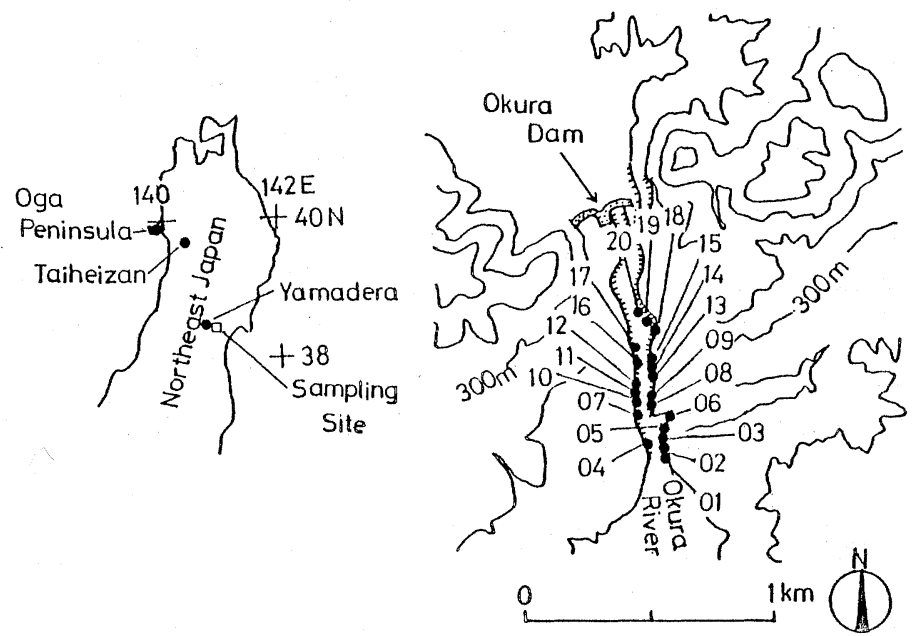

Fig. 1. Locality map of the Shimokura dike swarm and the sampling site of Nos. 01-20 $\left(140^{\circ} 43^{\prime} \mathrm{E}, 38^{\circ} 19^{\prime} \mathrm{N}\right)$. Contours of a $50 \mathrm{~m}$ interval are also shown.

twenty sites (Nos. 01-20) using gasoline-engine drills and magnetic compasses (Fig. 1). Nos. 3 and 4 samples were collected from the different outcrops of the same dike. Every specimen was subjected to stepwise demagnetization in alternating field and its remanence was measured with a spinner magnetometer. Optimum demagnetization steps were determined for individual dikes by the minimum dispersion criterion. Directions of stable remanent magnetization with precision parameters $(k$; FISHER, 1953) larger than 30 were obtained from fifteen dikes. Paleomagnetic results are listed in Table 1.

\section{Paleosecular Variation and Tectonic Implications}

All dikes showed reversed magnetization. Site-mean directions of remanent magnetization are illustrated in Fig. 2a by Lambert equal area projection. The average direction of site-mean ones and its $95 \%$ confidence circle are also shown in Fig. 2a. The directions indicate moderate dispersion around their mean and systematic declination shift by about $20^{\circ}$ from the axial dipole field in a counterclockwise sense. This shift will be discussed later. Corresponding virtual geomagnetic poles (VGPs, Fig. 2b) yield an angular standard deviation (ASD) of $14.1^{\circ}$ with a $95 \%$ confidence interval between $11.4^{\circ}$ and $18.7^{\circ}$. In a zone of the Japanese latitude, the paleosecular variation is characterized by the $14^{\circ}-15^{\circ}$ ASD of VGPs during the Brunhes epoch when averaged over a sufficient time span (McElHinNy and MerRil, 1975; HeKI, 1983). The between-site ASD for the Shimokura dike swarm at the time of reversed polarity about $8 \mathrm{MaBP}$ accords well with this value. 
Table 1. Paleomagnetic results and strike directions of the Shimokura dike swarm.

\begin{tabular}{|c|c|c|c|c|c|c|c|c|c|c|}
\hline \multirow[t]{2}{*}{ Dike } & \multirow[t]{2}{*}{$N$} & \multirow[t]{2}{*}{ Incl. } & \multirow[t]{2}{*}{ Decl. } & \multirow[t]{2}{*}{$k$} & \multirow[t]{2}{*}{$\alpha_{95}$} & \multicolumn{2}{|c|}{ VGP } & \multirow{2}{*}{$\begin{array}{l}\mathrm{CDF} \\
(\mathrm{mT})\end{array}$} & \multirow[t]{2}{*}{ Strike } & \multirow{2}{*}{$\begin{array}{l}\text { Rock } \\
\text { Type }\end{array}$} \\
\hline & & & & & & Lat. & Long & & & \\
\hline 01 & 4 & $-53.1^{\circ}$ & $157.9^{\circ}$ & 625 & $3.7^{\circ}$ & $71.6^{\circ} \mathrm{S}$ & $222.9^{\circ} \mathrm{E}$ & 5 & $\mathrm{~N} 83^{\circ} \mathrm{E}$ & B \\
\hline 02 & 4 & -62.9 & 141.0 & 913 & 3.0 & 60.4 & 255.1 & 10 & 63 & $\mathrm{D}$ \\
\hline 03,04 & 8 & -68.5 & 145.7 & 356 & 2.9 & 62.6 & 271.4 & 10 & 63 & $\mathrm{D}$ \\
\hline 05 & 4 & -65.5 & 140.8 & 269 & 5.6 & 60.2 & 261.8 & 15 & 61 & A \\
\hline 06 & 4 & -72.2 & 150.8 & 399 & 4.6 & 63.1 & 285.1 & 10 & 53 & A \\
\hline 07 & 4 & -48.2 & 173.1 & 271 & 5.6 & 79.3 & 175.0 & 5 & 13 & B \\
\hline 08 & 4 & -46.7 & 163.5 & 39 & 14.9 & 72.8 & 198.6 & 5 & 23 & B \\
\hline 09 & 4 & -60.6 & 167.9 & 245 & 5.9 & 80.2 & 254.0 & 10 & 65 & B \\
\hline 10 & 4 & -64.7 & 161.4 & 265 & 5.7 & 74.0 & 268.0 & 10 & 37 & B \\
\hline 11 & 4 & -61.1 & 157.7 & 179 & 6.9 & 72.6 & 250.6 & 10 & 39 & B \\
\hline 12 & 4 & -75.7 & 156.0 & 212 & 6.3 & 61.4 & 298.0 & 10 & 55 & A \\
\hline 13 & 4 & -57.0 & 173.1 & 38 & 15.2 & 84.5 & 225.4 & 10 & 51 & B \\
\hline 15 & 4 & -61.2 & 177.9 & 63 & 11.7 & 85.7 & 299.5 & 15 & 53 & B \\
\hline 16 & 4 & -50.8 & 162.1 & 99 & 9.3 & 73.9 & 211.2 & 15 & 33 & B \\
\hline 17 & 4 & -73.8 & 195.5 & 412 & 4.5 & 66.3 & 340.2 & 15 & 37 & A \\
\hline \multicolumn{11}{|c|}{ Mean field } \\
\hline & 15 & -62.1 & 162.0 & 55 & 5.2 & - & - & - & - & \\
\hline \multirow[t]{2}{*}{ Mean } & VGP & & & & & & & & & \\
\hline & 15 & - & - & 31 & 7.0 & 75.0 & 261.0 & \multicolumn{3}{|c|}{$\left(\mathrm{ASD}=14.1^{\circ}\right)$} \\
\hline
\end{tabular}

$N$ : number of samples, Incl.: mean inclination, Decl.: mean declination, $k$ : precision parameter by FISHER (1953), $\alpha_{95}$ : radius of $95 \%$ confidence circle. Lat.: latitude, Long.: longitude, ODF: optimum demagnetization field, ASD: angular standard deviation. The 03 and 04 samples were collected from different outcrops of the same dike. The $\mathrm{K}-\mathrm{Ar}$ ages of $7.9 \mathrm{MaBP}$ (No. 03) and 8.2 MaBP (No. 06) were reported by TSUNAKAWA et al. (1983). Rock type: A, andesitic, B, basaltic, $\mathrm{D}$, dacitic.

The between-site mean direction of remanent magnetization for the Shimokura dike swarm has $I=-62.1^{\circ}$ and $D=162.0^{\circ}$ with a $95 \%$ confidence circle of $5.2^{\circ}$. This declination shows a counterclockwise shift of about $20^{\circ}$ from the axial dipole field. The ASD value of about $14^{\circ}$ infers that the mean direction averages out the secular variation. The horizontal bedding plane of the host tuffs indicates no significant tilting after intruding of the Shimokura dikes. The declination shift is, therefore, interpreted as a result of tectonic rotation of this area after $8 \mathrm{MaBP}$. The paleomagnetic results for the Yamadera and Taiheizan samples (see Fig. 1), obtained by ОтоғUл et al. (1984), show a similar declination shift. However, TosHA (1984) reported that the paleomagnetic results of the Oga Peninsula region (see Fig. 1) in the west side of Northeast Japan show a counterclockwise rotation of about $50^{\circ}$ during about $15-22 \mathrm{MaBP}$ and that no significant tectonic rotation occurred in the Oga region after about $15 \mathrm{MaBP}$. We show the mean VGPs obtained by the present study, OTоFUлI et al. (1984) and TosHA (1984) in Table 2 and Fig. 3. It is a serious problem whether or not the tectonic rotation inferred from these paleomagnetic studies is applicable to the surroun- 


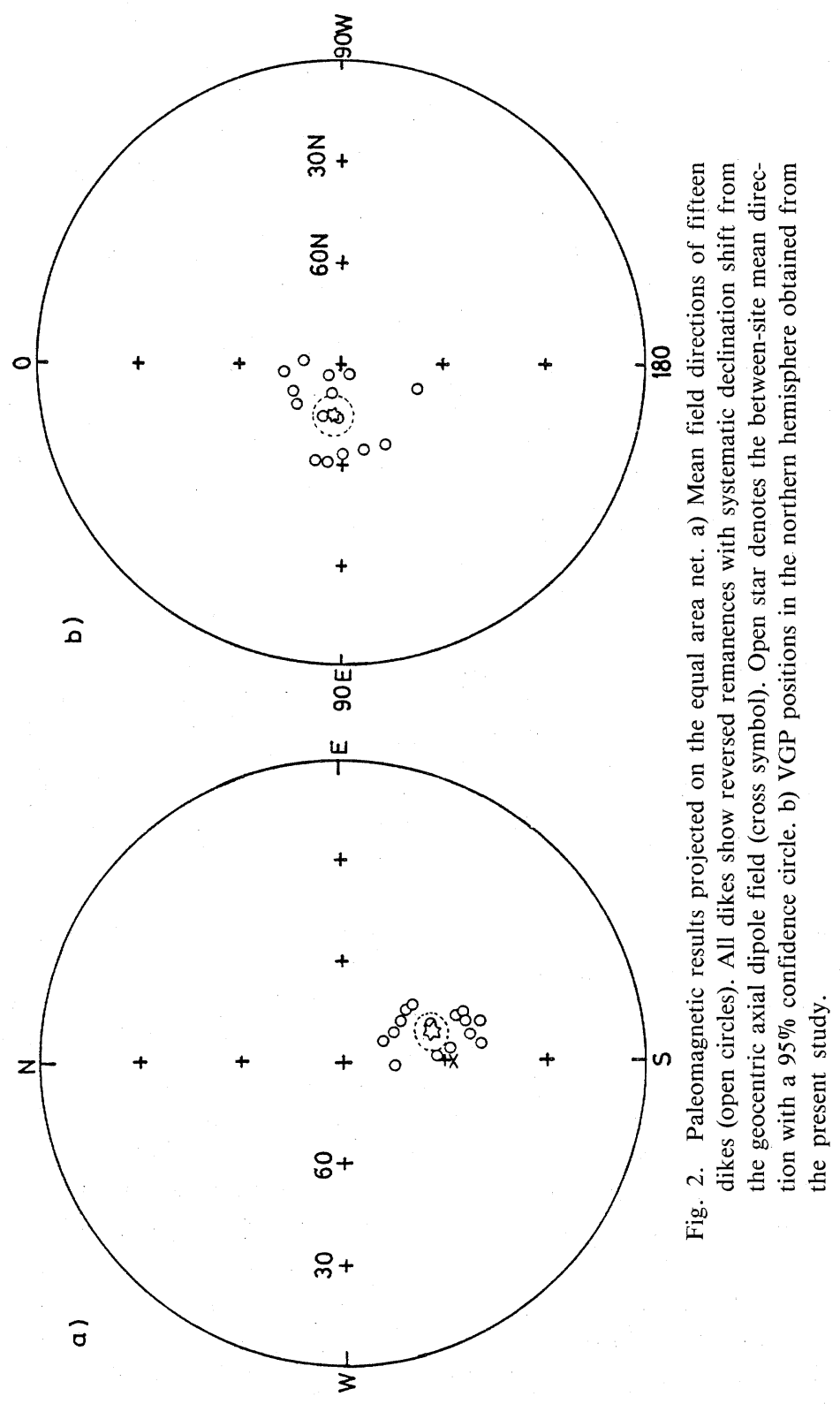


Table 2. Mean VGPs in northern hemisphere reported on the Middle to Late Miocene rocks in Northeast Japan.

\begin{tabular}{lrllllll}
\hline Locality & $N$ & Lat. & Long. & $K$ & A95 & Age & Ref. \\
\hline Shimokura & 15 & $75.0^{\circ} \mathrm{N}$ & $81.0^{\circ} \mathrm{E}$ & 31 & 7.0 & $8 \mathrm{MaBP}$ & This study \\
Yamadera and & 4 & 70.2 & 80.7 & - & - & $11-14 \mathrm{MaBP}$ & $\begin{array}{l}\text { OTOFUJI } \text { et al. } \\
\text { Taiheizan }\end{array}$ \\
\begin{tabular}{l} 
Oga Peninsula \\
\hline
\end{tabular} & 9 & 86.0 & -87.9 & - & - & $12-17 \mathrm{MaBP}$ & TOSHA (1984) \\
\hline
\end{tabular}

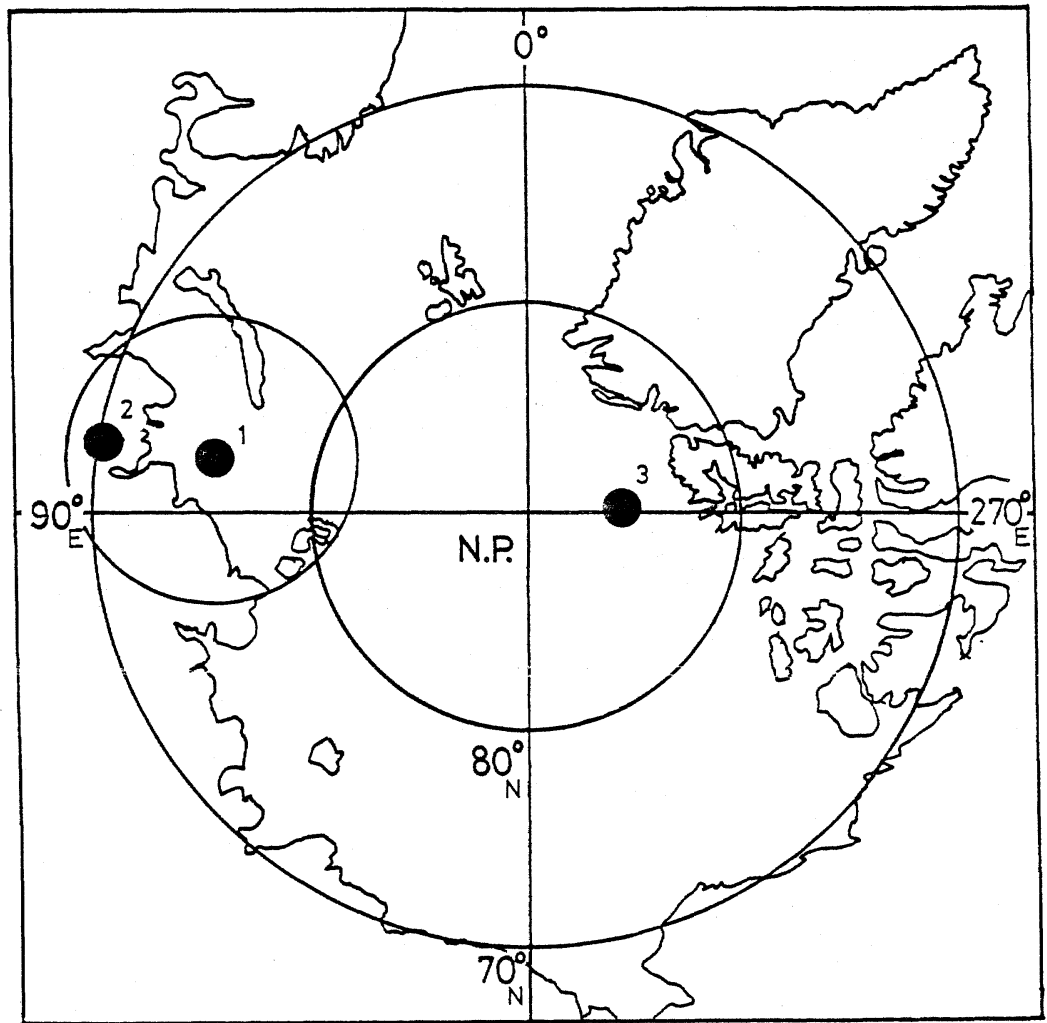

Fig. 3. Mean VGP positions listed in Table 2. (1) the Shimokura dike swarm by the present study with a $95 \%$ confidence circle, (2) the Yamadera and Taiheizan by OTOFUJI et al. (1984), (3) the Oga Peninsula by Tosha (1984).

ding region of sampled areas. Further accumulation of paleomagnetic data will reveal the coherency of tectonic movement in Northeast Japan.

We can estimate the direction of horizontal maximum stress field $\left(\sigma_{\mathrm{Hmax}}\right)$ from a dominant strike of dike swarm (NAKAMURA, 1977). The Rose diagram 
of strikes for the Shimokura dike swarm is shown in Fig. 4 and indicates a dominant strike of $\mathrm{N} 60 \mathrm{E}$. The $\sigma_{\mathrm{Hmax}}$ is, therefore, inferred to have an in-situ direction of $\mathrm{N} 60 \mathrm{E}$. When we take the counterclockwise rotation of about $20^{\circ}$ into account, the $8 \mathrm{MaBP} \sigma_{\mathrm{H} \max }$ direction becomes a $\mathrm{N} 80 \mathrm{E}$, nearly an $\mathrm{E}-\mathrm{W}$ trend. This $\sigma_{\mathrm{H} \max }$ direction is in accord with that of the E-W compressional stage in the southern part of Northeast Japan since about 8MaBP (TsUNAKAWA, 1985). SATO et al. (1982) suggested that the $\sigma_{\mathrm{H} \max }$ directions are characterized by NE-SW and NW-SE trends in the northern part of Northeast Japan whilst these are by E-W and N-S trends in the southern part (TAKEUCHI, 1981; TSUNAKAWA, 1985). This difference is possibly attributed to the tectonic rotation of the northern part after the Late Miocene.

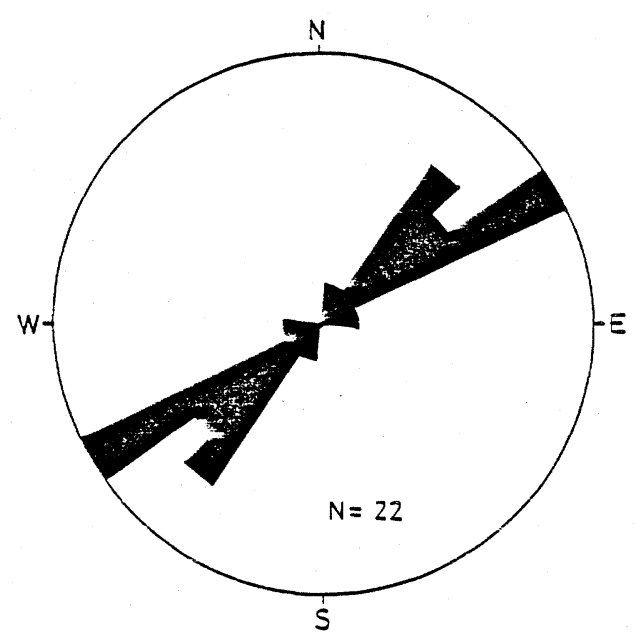

Fig. 4. Rose diagram of twenty-two dikes in the Shimokura dike swarm. These dikes include those used in the present study (twenty dikes) and others observed within the sampled area (two dikes).

\section{Summary}

The paleomagnetic study of the Shimokura dike swarm gave the ASD of the paleosecular variation of $14.1^{\circ}$ at the time of reversed polarity about $8 \mathrm{MaBP}$. This ASD value is comparable to that observed in Japan in the Brunhes epoch. Mean field direction shows a counterclockwise declination shift of about $20^{\circ}$ from the axial dipole field. This shift suggests that the sampled area of the Shimokura dike swarm in the northern part of Northeast Japan has undergone the tectonic rotation in a counterclockwise sense after $8 \mathrm{MaBP}$. Further paleomagnetic studies will clarify more detailed features of the tectonic movement in Northeast Japan. 
We thank Prof. M. Kono, Tokyo Institute of Technology, and Drs. T. Tosha and Y. Takigami, University of Tokyo, for collaboration in sampling.

\section{REFERENCES}

Amano, K., Geology of the Ou Backbone Ranges in Miyagi and Yamagata Prefectures, Northeast Japan, Contr. Inst. Geol. Pal. Tohoku Univ., 81, 1-56, 1980 (in Japanese with English abstract).

Fisher, R. A., Dispersion on a sphere, Proc. R. Soc., Ser. A., 217, 295-305, 1953.

HEKI, K., Paleomagnetic study of the Higashi-Izu monogenetic volcano group and pyroclastic flow deposits in Kagoshima Prefecture: paleosecular variation during the last 40,000 years in Japan, J. Geomag. Geoelectr., 35, 383-390, 1983.

KATO, Y., A. TAKAGI, and I. KATO, Reverse remanent magnetism of dyke of basaltic andesite, J. Geomag. Geoelectr., 6, 206-207, 1954.

Kuno, H., Volcanoes and Volcanic Rocks, 2nd ed., pp. 283, Iwanami, 1976 (in Japanese).

MCELhinny, M. W. and R. T. Merill, Geomagnetic secular variation over the past 5 m.y., Rev. Geophys. Space Phys., 13, 687-708, 1975.

NAKAMURA, K., Volcanoes as possible indicators of tectonic stress orientation-principle and proposal, J. Volcanol. Geotherm. Res., 2, 1-16, 1977.

Otofuji, Y., T. MAtsuda, and S. NOHDA, Paleomagnetic evidence for the Miocene counterclockwise rotation of Northeast Japan, submitted to Earth Planet. Sci. Lett., 1984.

Sato, H., K. OTSuKi, and K. Amano, Neogene tectonic stress field of Northeast Honshu arc, Circular Res. Assoc. Structur. Geol., 27, 55-79, 1982 (in Japanese).

TAKEUCHI, A., Temporal changes of regional stress field and tectonics of sedimentary basin, $J$. Geol. Soc. Japan, 87, 737-751, 1981 (in Japanese with English abstract).

ToshA, T., Paleomagnetism of northeast Japan, Doc. Thesis, Faculty of Sci., Univ. Tokyo, Japan, 1984.

TSUNAKAWA, H., Neogene stress field of the Japan Arc and its relation to the igneous activity, submitted to Tectonophysics, 1985.

TSUnAKAWA, H., A. TAKEUCHI, and K. AMANO, K-Ar ages of dikes in Northeast Japan, Geochem. J., 17, 269-275, 1983. 